\title{
Furunculosis in baitfish and its transmission to salmonids
}

\author{
V. E. Ostland ${ }^{1}$, B. D. Hicks ${ }^{1}$ \& J. G. Daly ${ }^{2}$ \\ ${ }^{1}$ Fish Pathology Laboratory, Department of Pathology, Ontario Veterinary College, University of Guelph, Guelph, Ontario \\ N1G 2W1, Canada \\ ${ }^{2}$ Department of Microbiology, College of Biological Science, University of Guelph, Guelph, Ontario N1G 2W1, Canada
}

\begin{abstract}
Aeromonas salmonicida subsp. salmonicida was isolated from 4 species of freshwater minnows commonly used as baitfish. Some of the infected baitfish developed deep-seated muscle lesions (furuncles) similar to those seen in salmonids with furunculosis. In non-salmonids, furunculosis has previously been associated with superficial ulcerative lesions from which atypical $A$. salmonicida was usually isolated. This report illustrates the ability of $A$. salmonicida subsp. salmonicida to cause furunculosis in 4 species of baitfish. It was transmitted from one species of minnow, the common shiner Notropis cornutus, to coho salmon Oncorhynchus kisutch and brook trout Salvelinus fontinalis, demonstrating the potential for baitfish to serve as a reservoir for the horizontal transmission of typical $A$. salmonicida from non-salmonids to salmonids held in the same body of water.
\end{abstract}

\section{INTRODUCTION}

Furunculosis has been reported amongst numerous species of wild and captive fish. Either atypical or typical Aeromonas salmonicida can usually be isolated from affected fish.

The atypical group of Aeromonas salmonicida although sometimes recovered from salmonids (Paterson et al. 1980, Evelyn 1971) is usually reported from non-salmonids, including goldfish Carassius auratus (Elliot \& Shotts 1980, Trust et al. 1980), carp Cyprinus carpio (Bootsma et al. 1977), eel Anguilla japonica (Kitao et al. 1984), silverbream Blicca bjoerkna (McCarthy 1975), sablefish Anoplopoma fimbria (Evelyn 1971), dace Phoxinus phoxinus (Hastein et al. 1978), cod Gadus morhua (Cornick et al. 1984), yellow bass Morone mississipiensis (Buckley 1969) and smallmouth bass Micropterus dolomieui (Le Tendre et al. 1972).

The typical group, Aeromonas salmonicida subsp. salmonicida (Popoff 1984), is frequently isolated from salmonids (McCraw 1952, Paterson 1982, McCarthy \& Roberts 1980) and infrequently from non-salmonids, for example wild sculpins Cottus bairdi (Rabb \& McDermott 1962), goldfish Carassius auratus (MawdeslayThomas 1969), and eels Anguilla rostrata (Hayasaka \& Sullivan 1981). Since this bacterial pathogen is wide- spread within fish populations (McCarthy \& Roberts 1980), and because horizontal transmission is known to occur (Cipriano 1982), the potential for epizootics in captive fish and the spread of infection amongst a variety of fish species exists. This paper reports an outbreak of furunculosis caused by $A$. salmonicida subsp. salmonicida in 4 species of freshwater baitfish. To the best of our knowledge this disease has never previously been reported in the creek chub, common shiner, golden shiner and white sucker. We have also demonstrated that furunculosis can be transmitted from the common shiner to coho salmon and brook trout.

\section{MATERIALS AND METHODS}

Forty-eight common shiners Notropis cornutus, 48 white suckers Catostomus commersoni, 12 creek chub Semotilus atromaculatus and 12 golden shiners Notemogonus crysoleucas were purchased as a mixed lot on April 18 from a commercial baitfish dealer. These fish were collected from a variety of watersheds in southern Ontario, Canada, and held in concrete pools (approximately $2 \mathrm{~m}$ square and $1 \mathrm{~m}$ deep) which were supplied with ground water and aerated by surface agitation. At the time of purchase, the age of the fish, length of time in captivity, and water temperature were unknown. 
The fish were transported in new polyethylene bags to the Laboratory Animal Building, University of Guelph, Guelph, Ontario, Canada, and held in flowthrough plastic 701 aquaria supplied with dechlorinated municipal tap water $\left(10 \pm 1^{\circ} \mathrm{C}\right)$ at a rate of approximately $0.7 \mathrm{l} \mathrm{min}{ }^{-1}$. All aquaria received supplemental aeration. The fish were fed once daily to satiation with commercial trout pellets.

Two days after purchase, 6 common shiners, 3 white suckers and 5 creek chub were found dead. During the following $18 \mathrm{~d}, 42$ fish died. Eight fish were necropsied and sampled for histopathology and bacteriology, and 3 additional fish were sampled for bacteriology only.

Eight common shiners from this shipment were moved to a separate building and placed in a $500 \mathrm{l}$ tank containing 200 yearling coho salmon Oncorhynchus kisutch in an attempt to horizontally transmit furunculosis. The coho salmon (approximately $10 \mathrm{~cm}$ in length) were obtained from a provincial fish culture station with no previous history of furunculosis. These fish were, however, known carriers of Renibacterium salmoninarum, the causative agent of bacterial kidney disease (BKD). Uninfected, negative controls were kept at the fish culture station.

In another experiment, approximately $500 \mathrm{ml}$ of water and feces from the effluent fecal trap of the tank containing the common shiners and coho salmon was poured directly into one of 10 experimental tanks each containing 50 brook trout Salvelinus fontinalis of age $1 \mathrm{yr}$. The remaining 9 tanks served as uninfected controls. These trout had been raised from eggs of certified specific pathogen-free brood stock (Department of Fisheries and Oceans 1984) and had a disease-free history. Both horizontal transmission experiments were carried out at $10^{\circ} \mathrm{C}$ in dechlorinated municipal water that experience had shown to be free of Aeromonas salmonicida.

Samples for histopathology were placed in Bouin's fixative for $24 \mathrm{~h}$. Multiple cross sections of the fish were dehydrated with alcohol, embedded in paraffin wax, sectioned at $6 \mu \mathrm{m}$, stained with hematoxylin and eosin (H\&E) and examined microscopically. Samples for bacteriology from kidney and skin lesions were inoculated onto Trypticase Soy Agar and incubated at $20^{\circ} \mathrm{C}$ for $48 \mathrm{~h}$

Bacterial isolates that produced a brown, diffusing pigment were characterized by the following criteria: Gram's stain, motility in tryptic Soy broth at $20^{\circ} \mathrm{C}$. ability to grow at $37^{\circ} \mathrm{C}$ and cytochrome oxidase reaction. Slide agglutination reactions were performed with rabbit anti-Aeromonas salmonicida serum. Nonimmune rabbit serum was used as a negative control. Isolates that autoaggregated were placed in a boiling water bath for $20 \mathrm{~min}$. The isolates were further characterized for their ability to produce indole in tryptone broth, to produce lysine and ornithine decarboxylases to produce arginine dihydrolase (Moeller's method), to utilize citrate (Simmons'), to ferment mannitol and to hydrolyze esculin. The tests were carried out for $7 \mathrm{~d}$ at $20^{\circ} \mathrm{C}$ according to the methods described by MacFaddin (1976).

\section{RESULTS}

Forty $\%$ of the common shiners, $33 \%$ of the white suckers and all of the creek chub and the golden shiners became moribund during the initial $3 \mathrm{wk}$ in our holding facilities. These fish had characteristic lesions associated with furunculosis. They were hyperemic at the base of the fins and vent, and most fish had focal epithelial ulceration often extending into the underlying musculature. Two of the creek chub and one of the suckers exhibited focal liquefactive necrosis of the axial musculature producing the so-called furuncle of furunculosis. Histologic lesions included multifocal bacterial branchitis, myocarditis, myositis, hepatitis, splenitis, nephritis and dermatitis, all of which contained obvious bacterial colonies. Minimal inflammatory cell infiltration was associated with these multifocal lesions.

The dead fish sampled for bacteriological examination included 4 common shiners, 3 white suckers, 3 creek chub and 1 golden shiner. All fish yielded brown pigment producing isolates as axenic cultures from the kidneys

Seventeen $d$ after the common shiners had been placed with the coho salmon, one of the shiners died. During the next $30 \mathrm{~d}$ the 7 remaining shiners and 30 of the 200 coho salmon also died. The shiners were hyperemic at the base of fins and vent and had histological lesions similar to the lesions described above. Bacterial isolates which produced a brown diffusing pigment were recovered as axenic cultures from all 8 shiners and 2 of the coho salmon. Since none of the control group of salmon remaining at the fish culture station developed furunculosis, and since the test salmon were held in a water supply considered to be free of Aeromonas salmonicida, we suggest that the 2 coho salmon that died of furunculosis did so as a result of infections contracted from the shiners. The remaining 28 coho salmon had swollen bulbous kidneys, which contained multifocal, greyish-white nodules. Gramstained kidney smears contained large numbers of Gram-positive diplobacilli confirmed to be Renibacterium salmoninarum using the indirect fluorescent antibody technique (Bullock \& Stuckey 1975). These fish likely died of bacterial kidney disease.

Three wk after feces and detritus from the tank containing the shiners and coho salmon tank were 
introduced into the brook trout tank, the brook trout began dyind. All 50 fish exposed to the contaminated effluent became moribund and developed the typical furunculosis lesions of deep-seated muscle necrosis associated with furunculosis. Axenic cultures of a brown, pigment producing isolate were recovered from the kidneys and skin lesions. The brook trout in the 9 control tanks remained healthy throughout the experimental period. None of the brook trout developed bacterial kidney disease lesions.

The brown pigmented bacteria isolated from the minnows, coho salmon and brook trout were identical. They were Gram negative, non-motile, failed to grow at $37^{\circ} \mathrm{C}$ and were cytochrome oxidase positive. All strains autoagglutinated in non-immune rabbit serum. After boiling in a waterbath, the bacteria no longer autoagglutinated and were agglutinated by rabbit antiAeromonas salmonicida serum. Further tests revealed that the bacteria produced arginine dihydrolase and failed to produce lysine and ornithine decarboxylases and indole. The bacteria did not ferment sucrose or utilize citrate, but fermented mannitol and hydrolysed esculin. These results identified the bacteria as Aeromonas salmonicida subsp. salmonicida (Popoff 1984).

\section{DISCUSSION}

Furunculosis in salmonids is usually associated with strains of Aeromonas salmonicida subsp. salmonicida while atypical strains of $A$. salmonicida are usually associated with dermal ulceration in non-salmonids (Paterson 1982). The physiological characteristics of the bacteria isolated from the diseased baitfish indicate that these strains are members of the typical $A$. salmonicida subsp. salmonicida. This paper demonstrates that $A$. salmonicida subsp. salmonicida can cause furunculosis in at least 4 species of freshwater baitfish and that under our experimental conditions, baitfish can serve as a reservoir of infection for salmonids.

Typical strains of Aeromonas salmonicida are known to occur in feral brown trout Salmo trutta, wild brook trout and sculpins in southern Ontario (Rabb \& McDermott 1962, Daly \& Stevenson 1985). The present outbreak of typical furunculosis in baitfish is probably an example of clinical disease developing or recrudescing in a population of asymptomatic carrier fish which had been severely stressed during capture, transportation and holding. Furunculosis in baitfish is probably more common than suggested by the paucity of published reports on this topic (Rabb \& McDermott 1962, Hastein et al. 1978, Mitchum 1981). The practice of discarding moribund baitfish without a pathological examination (Toth 1983) makes it impossible to accurately document the enzootic nature of furunculosis in baitfish.
The deep-seated muscle pathology of furunculosis associated with Aeromonas salmonicida subsp. salmonicida may occur in non-salmonids (this report) as well as salmonids (Ferguson \& McCarthy 1978, McCarthy \& Roberts 1980). Some authors (McCarthy \& Roberts 1980, Paterson 1982) have suggested that furunculosis in non-salmonids be distinguished from furunculosis in salmonids on the basis of the more superficial appearance of the ulcers in non-salmonids and their association with atypical strains of $A$. salmonicida. We have shown that typical furunculosis associated with A. salmonicida subsp. salmonicida can occur in non-salmonids such as baitfish. This suggests that the superficial appearance of the lesions and the species of fish involved may not be reliable criteria for establishing a definitive diagnosis. Regardless of the species of fish affected, bacteriological examination would be required to establish a definitive diagnosis.

Acknowledgements. We thank Dr. H. W. Ferguson for his interest and helpful suggestions. Ms. Sandy Brown skillfully typed the manuscript. Partial funding was provided by the Ontario Ministry of Natural Resources and the Ontario Ministry of Agriculture and Food. JGD was the recipient of an Ontario Graduate Scholarship.

\section{LITERATURE CITED}

Bootsma, R., Fijan, N., Blommaert, J. (1977). Isolation and preliminary identification of the causative agent of carp erythrodermatitis. Vet. Archiv 47: 291-302

Buckley, R. V. (1969). A furunculosis epizootic in Clear Lake yellow bass. Bull. Wildl. Dis. Assoc. 5: 322-327

Bullock, G. L., Stuckey, H. M. (1975). Fluorescent antibody identification and detection of the Corynebacterium causing kidney disease of salmonids. J. Fish. Res. Bd Can. 32: 2224-2227

Cipriano, R. C. (1982). Furunculosis in brook trout: infection by contact exposure. Prog. Fish Cult. 44: 12-14

Cornick, J. W., Morrison, C., Zwicker, B., Shum, G. (1984). Atypical Aeromonas salmonicida infection in Atlantic cod, Gadus morhua L. J. Fish Dis. 7: 495-499

Daly, J. G., Stevenson, R. M. W. (1985). Importance of culturing several organs to detect Aeromonas salmonicida in salmonid fish. Trans. Am. Fish. Soc. 114: 909-910

Department of Fisheries and Oceans (1984). Fish health protection regulations: manual of compliance. Fish. Mar. Serv. Misc. Spec. Publ. 31 (Revised): p. 1-43

Elliot, D. G., Shotts, E. B. Jr. (1980). Aetiology of an ulcerative disease in goldfish Carassius auratus (L.): microbiological examination of diseased fish from seven locations. J. Fish Dis. 3: $133-143$

Evelyn, T. P. T (1971). An aberrant strain of the bacterial fish pathogen Aeromonas salmonicida isolated from a marine host, the sablefish, Anoplopoma fimbria, and from two species of cultured Pacific salmon. J. Fish. Res. Bd Can. 28: $1629-1634$

Ferguson, H. W., McCarthy, D. H. (1978). Histopathology of furunculosis in brown trout Salmo trutta L. J. Fish Dis. 1: $165-174$

Hastein, T., Saltveit, S. J., Roberts, R. J. (1978). Mass mortality 
among minnows Phoxinus phoxinus (L.) in Lake Tveitevata, Norway, due to an aberrant strain of Aeromonas salmonicida. J. Fish Dis. 1: 241-249

Hayasaka, S. S., Sullivan, J. (1981). Furunculosis in cultured American eel Anguilla rostrata (Le Sueur). J. Fish Biol. 18: 655-659

Kitao, T., Yashida, T., Aoki, T., Fukudome, M. (1984). Atypical Aeromonas salmonicida, the causative agent of an ulcer disease of eel occurred in Kagoshima Prefecture. Fish Path. 19: 113-117

Le Tendre, G. C., Schneider, C. P., Ehlinger, N. F. (1972). Net damage and subsequent mortality from furunculosis in smallmouth bass. N. Y. Fish Game J. 19: 73-82

MacFaddin, J. F. (1976). Biochemical tests for identification of medical bacteria. Williams and Wilkins, Baltimore

Mawdesley-Thomas, L. E. (1969). Furunculosis in the goldfish Carassius auratus L. J. Fish Biol. 1: 19-23

McCarthy, D. M. (1975). Fish furunculosis caused by Aeromonas salmonicida var. achromogenes. J. Wildi. Dis. 11: 489-493

McCarthy, D. H., Roberts, R. J. (1980). Furunculosis of fish the present state of our knowledge. Adv. Aquat. Microbiol. 2: $293-342$

McCraw, B. M. (1952). Furunculosis of fish. U. S. Fish and Wildlife Services, Special Scientific Report 84
Mitchum, D. L. (1981). Concurrent infections: ERM, furunc found in emerald shiners. FHS/AFS Newsletter 9 (4): 2

Paterson, W. D. (1982). Furunculosis and other associated diseases caused by Aeromonas salmonicida. In: Anderson, D. P., Dorson, M., Deubourget, P. H. (ed.) Antigens of fish pathogens: development and production for vaccines and serodiagnostics. Collection of Foundation Marcel Merieux, Lyon, p. 119-137

Paterson, W. D., Douey, D., Desautels, D. (1980). Isolation and identification of an atypical Aeromonas salmonicida causing epizootic losses among Atlantic salmon (Salmo salar) reared in a Nova Scotian hatchery. Can. J. Fish. Aquat. Sci. 37: 2236-2241

Popoff, M. (1984). Genus III. Aeromonas Kluyrer and Van Niel 1936, 398. In: Krieg, N. R. (ed.) Bergey's manual of systematic bacteriology. Williams and Wilkins, Baltimore, $p$. 545-548

Rabb, L., McDermott, L. A. (1962). Bacteriological studies of freshwater fish. II. Fununculosis in Ontario fish in natural waters. J Fish. Res. Bd Can. 19: 989-995

Toth, G. (1983). Status of the commercial bait fish industry in Ontario. Aquaculture Development Program, Owen Sound

Trust, T. J., Khouri, A. G., Austen, R. A., Ashbumer, D. (1980). First isolation in Australia of atypical Aeromonas salmonicida. FEMS Microbiol. Lett. 9: 39-42

Responsible Subject Editor: Dr. T. Evelyn; accepted for printing on March 12, 1987 